\title{
Fotografia w polskim systemie prasowym
}

$\mathrm{F}$ otografia prasowa nie jest częstym tematem rozważań prasoznawców, chociaż stanowi nieodłączny składnik współczesnych dzienników i czasopism. Trudno znaleźć o niej ciekawe artykuły w zarówno w książkach, jak i prasie specjalistycznej. Natomiast nie brakuje pozycji traktujących o praktyce fotografii i o czysto technicznych aspektach jej uprawiania, przedstawionych w charakterze ilustrowanych poradników. Wśród tej literatury trudno jednak znaleźć publikację traktującą o teorii fotografii, jej systematyce, ontologii czy historii. Nieliczne pozycje ukazujące się na ten temat odwołują się w większości do fotografii artystycznej, a ich autorzy zaledwie zauważają zjawisko dziennikarstwa fotograficznego.

Do tej pory pojawiły się jedynie dwie książki, których autorzy zdecydowali się bezpośrednio podjąć tematykę fotografii prasowej: Zaranie fotografii dziennikarskiej w Polsce - autorstwa jednego z pionierów polskiego dziennikarstwa fotograficznego, Mariana Fuksa, opublikowana w 1925 roku w Warszawie oraz Fotografia prasowa a prawo Bogdana Michalskiego, wydana także w Warszawie w 1980 roku. Obie pozycje traktują fotografię prasową tylko w niektórych aspektach. W przypadku pracy Fuksa jest to próba opisania genezy fotografii na łamach polskiej prasy, natomiast praca Michalskiego zajmuje się rozważaniami czysto prawniczymi, w odniesieniu do nieobowiązujących już dzisiaj aktów normatywnych.

Wobec szczątkowych informacji na temat fotografii prasowej zawartych w książkach, podstawą literatury przedmiotu stały się rozproszone po różnych pismach artykuły prasowe, jednak niewiele z nich nawiązuje bezpośrednio do tematu, a problem fotografii prasowej jest w nich traktowany bardzo pobieżnie. Najbardziej pomocne okazały się tutaj publikacje w miesięczniku, a później kwartalniku „Fotografia”, który swoim poziomem znacznie odbiegał od nieprofesjonalnych wywodów zawartych w „Foto” czy „Foto Kurierze”. 
Udzielenie jednoznacznej odpowiedzi na pytanie, czym jest fotografia, i to odpowiedzi spełniającej, w pewnej chociażby mierze, oczekiwania konkretnego rozmówcy, jest rzeczą o tyle trudną, ponieważ stopień zaspokojenia ciekawości przejawiającej się w tak stawianym pytaniu zawsze będzie niepełny. Słowa „fotografia” (pochodzące z greki, phos światło, grapho - piszę) po raz pierwszy użył w 1839 roku, angielski fizyk, astronom i chemik John Frederick William Herschel, który jest również autorem określeń „negatyw” i „pozytyw”. W najogólniejszym pojęciu fotografia jest dziedziną wiedzy, techniki, rzemiosła i sztuki zarazem. Wszelkie definicje, jakimi próbują określić zjawisko i przedmiot fotografii różne słowniki i encyklopedie, są przeważnie niepełne i uwzględniają zazwyczaj tylko niektóre jej aspekty.

Krytyk i historyk fotografii, Juliusz Garztecki, poszukując możliwie najpełniejszego określenia istoty fotografii w postaci zwięzłej definicji, doszedł do następującego sformułowania: „Fotografia jest to sposób uzyskiwania trwałych, nieruchomych obrazów stanów chwilowych rzeczywistości wizualnej przez rejestrowanie w podłożu materialnym, fluktuacji poziomów energii promienistej w postaciach kwantowalnych"2.

Ta ściśnięta do ostatecznych możliwości informacja o istocie fotografii niewiele jednak mówi przeciętnemu człowiekowi. Fotografia jest dziedziną wiedzy i techniki. W tym rozumieniu składają się na nią różnorodne gałęzie nauk technicznych: fotochemia, optyka precyzyjna, a ostatnio informatyka. Postępowi w tych dziedzinach zawdzięczamy powstanie i rozwój materiałów światłoczułych, które umożliwiają zapisywanie na nich wspomnianej „fluktuacji poziomów energii promienistej”, skonstruowanie obiektywów i aparatów fotograficznych, kształtujących wiązki tej energii tak, by tworzyły rozpoznawalny obraz rzeczywistości, będący jej odbiciem.

Fotografia to właśnie narzędzie rejestracji „rzeczywistości wizualnej”, a więc cała jej technologia od chwili mrugnięcia migawki do momentu, kiedy w rękach znajdzie się gotowy obraz - ostateczny produkt tej technologii, a także i ten właśnie obraz noszący przecież identyczne określenie fotografia. Wszechstronne to i doskonałe narzędzie rejestracji, z równym powodzeniem, jak mowa i pismo, nadaje się do zapisu obrazów przyrody, jej tworów, jak i tego wszystkiego, co stworzyły umysł i ręka ludzka, do chwytania ulotnych chwil i zdarzeń w życiu jednostek oraz społeczeństw,

1 H. Łatoś, 1000 stów o fotografii, Warszawa 1982, s. 89-90.

2 J. Garztecki, Trzecie oko, Kraków 1975, s. 15. 
w przeobrażaniu się świata materialnego, w procesach chemicznych i fizycznych.

Aparat fotograficzny „znalazł” się, bowiem nie tylko w ręku fotografa portretowego, pejzażysty, reportera, ale także w pracowniach uczonych, w przemyśle, medycynie, astronomii, geofizyce, geologii, archeologii, kartografii, kryminalistyce. Trudno wyliczyć wszystkie gałęzie nauki i techniki, w których znalazła zastosowanie fotograficzna rejestracja stanów i przebiegów zjawisk interesujących badacza i praktyka. Wreszcie fotografia to współczesna gałąź sztuki wizualnej ze swoistymi dla niej problemami z dziedziny historii, estetyki, kompozycji oraz spraw z pogranicza tych sztuk plastycznych, które ją zrodziły i które zostały potem przez nią stworzone: malarstwa, grafiki, filmu i telewizji.

Obraz fotograficzny jest znakiem jak litera, słowo, a nawet zdanie, ułatwiające porozumiewanie się między ludźmi. Stał się nowym, najbardziej uniwersalnym, środkiem przekazu, jednakowo zrozumiałym dla wszystkich, nie znającym barier językowych i narodowościowych, etnicznych, społecznych i kulturowych. W tej uniwersalności tkwi tajemnica powodzenia fotografii jako źródła informacji o otaczającym nas świecie, ludziach i wydarzeniach. Ale nie tylko w uniwersalności ,języka” odnajdujemy przyczynę historycznego i współczesnego powodzenia fotografii. Od fotografii wymagamy, by dostarczała nam nie tylko idealnego wyobrażenia o czymś, ale aby (w przeciwieństwie do sztuki) potwierdziła nam również istnienie przedmiotów.

Sensacją wynalazku fotograficznego jest to, że został stworzony pomost pomiędzy światem fizycznym a jego obrazowym przedstawieniem, który nie jest wyłącznie oparty na artystycznej fantazji i twórczej swobodzie człowieka. W myśl tego wynalazku nie istnieje żadna fotografia, przy której człowiek w momencie tworzenia obrazu pozostawiłby działanie kamery li tylko fizycznej zasadzie. Gdyby człowiek nie stał poza tym fizycznym procesem twórczym, byłby on zapewne wyłącznym twórcą fotografii: jego obrazy mogłyby wówczas jednak - tak jak u artysty - pretendować do idealnej twórczości, jednak nie posiadałyby fizycznej legitymacji. Od zdjęcia wymagamy bowiem owej fizycznej legitymacji. Jednocześnie stawiamy dziś fotografii wymagania duchowe. Na zdjęciu chcemy zobaczyć więcej niż same przedmioty. Kamera musi, zatem „fotografować również ich stronę duchową"3.

${ }^{3}$ K. Pawek, Kim jest czlowiek?, Katalog Wystawy Światowej. 
Wielkiej roli, jaką we współczesnym świecie ma do odegrania fotografia w dziele informowania, poszerzania wiedzy, kształtowania poglądów i postaw społecznych, politycznych i kulturowych, doszukiwać się trzeba, $\mathrm{z}$ jednej strony $\mathrm{w}$ jej uniwersalizmie, $\mathrm{z}$ drugiej zaś $\mathrm{w}$ jej immanentnym autentyzmie i pełnej wiarygodności proponowanych przez nią przedstawień. A że ponadto jest obdarzona zdolnością wzruszania, możliwością dostarczania wrażeń i przeżyć bądź to estetycznych, bądź bo intelektualnych, więc zapisać jej trzeba te możliwości ma konto dodatkowych aktywów, potęgujących siłę jej oddziaływania. Wymieniane poprzednio główne jej atuty: uniwersalizm i autentyzm, mają znaczenie podstawowe, zwłaszcza dla fotografii prasowej ${ }^{4}$.

Podziału fotografii możemy dokonać, stosując różne kryteria. Kierując się czysto technicznym aspektem, klasyfikacje te można mnożyć w nieskończoność. Np. w zależności od stosowanego materiału światłoczułego wyróżniamy fotografię: czarno-białą, barwną, negatywową, pozytywową, cyfrową, podczerwona, natychmiastową. Kierując się formatem uzyskanego obrazu uzyskujemy natomiast podział na fotografię: miniaturowa, małoobrazkową, średnioformatową i wielkoformatową itp.

$\mathrm{Na}$ potrzeby tego artykułu najbardziej odpowiednim kryterium podziału wydaje się jej przeznaczenie. Według niego w fotografii możemy wyróżnić trzy zasadnicze grupy:

- amatorska,

- artystyczna,

- użytkową.

Fotografią amatorską określa się wszelkie przejawy działalności fotograficznej, której przeznaczeniem jest użytek własny. Tematyka fotografii amatorskiej może być przeróżna: od rodzinnych zdjęć pamiątkowych, po makrograficzne obrazy miłośnika przyrody. Podstawową cechą fotografii amatorskiej jest jej niewysoka jakość, wynikająca z jednej strony z braku umiejętności fotografującego, a $\mathrm{z}$ drugiej strony $\mathrm{z}$ zastosowanego sprzętu (głównie optyki i elektroniki). Fotoamator, w zależności od swoich zdolności i wiedzy, z czasem zaczyna tworzyć obrazy, które nabierają cech pozostałych typów fotografii: artystycznej i użytkowej.

Fotografia artystyczna, nazwana także przez jej prekursora i ideologa w Polsce, Jana Bułhaka fotografika jest typem fotografii najtrudniejszym do zdefiniowania. Najkrócej można ją określić jako gatunek fotograficzny

4 W. Tatarkiewicz, Fotografie i obrazy, „Fotografia” 1977, nr 2, s. 2. 
mający na celu wywołanie przede wszystkim wrażeń estetycznych na skutek odbioru czegoś niepowtarzalnego, zawartego w kompozycji, barwie i świetle. W swej konwencji jest ona najbardziej zbliżona do malarstwa. Nie oznacza to jednak, że od razu była zaliczana do sztuk pięknych, a to ze względu na właściwy jej czynnik mechaniczny, na aparat, który poniekąd zastępuje w niej oko i rękę artysty. Rozumowano, że zdjęcia fotograficzne są wytworem aparatu. Wszakże rozumowanie takie nie było słuszne, bo $\mathrm{w}$ fotografice czynnika mechanicznego jest więcej niż w malarstwie i nie tylko w doborze tematu i kąta widzenia.

Trzecim gatunkiem fotografii jest fotografia użytkowa, zwana też stosowaną. Podstawowym jej wyróżnikiem jest ściśle określone zastosowanie. Fotografia ta jest wykonywana w z góry określonym celu. Do tego działu, fotografii zaliczamy między innymi: fotografię dokumentacyjną, reklamową, rzemieślniczo-usługową, katalogową, przemysłową, naukową i fotografię prasową 5 .

Konkretne zastosowanie fotografii, wymusza jej charakter. Każda z gałęzi fotografii użytkowej ma swoje reguły, których przestrzeganie jest gwarantem wykonania zdjęcia odpowiadającego wymogom odbiorcy. W ten sposób w fotografii katalogowej najważniejszą rzeczą jest oddanie detalu fotografowanego obiektu, aby odbiorca mógł z danego zdjęcia ustalić jak najwięcej jego cech. Z kolei dokumentacja sztuki polega na umiejętnym dobraniu odpowiedniego kąta i oświetlenia fotografowanego zabytku, w ten sposób, by nie zatracił on cech charakterystycznych dla epoki, w której powstał. Nawet zdjęcie legitymacyjne ma z góry ustalone zasady oświetlenia i kompozycji. Te reguły stanowią podstawową różnicę pomiędzy fotografią użytkową a artystyczną, dla której najważniejszą cechąjest niepowtarzalność i nowatorstwo zarówno w formie, jak i w treści.

Z prawnego punktu widzenia za fotografię prasową można uznać każdą fotografię spełniającą wymagania materiału prasowego. Ustawa z dnia 26 stycznia 1984 r. Prawo prasowe w art. 7 ust. 2 pkt 4 kwalifikuje m.in. fotografię jako „materiał prasowy”. Z zapisu tejże ustawy wynika, że każda fotografia, niezależnie czy będzie to ilustracja, zdjęcie reporterskie, fotoreportaż, zdjęcie promocyjne, czy reklamowe jest materiałem prasowym. Ustawodawca zastrzegł jednak warunek, jaki musi spełniać materiał prasowy. Jest to wymóg publikacji lub przekazania do publikacji w prasie. Kwestia zakwalifikowania zdjęcia do druku nie ma tutaj znacze-

5 H. Latoś, op. cit., s. 99. 
nia. Nie ma także znaczenia czy zdjęcie wykonał zawodowy fotograf, dziennikarz piszący, czy amator, który wysłał je do redakcji.

Kierując się zatem tylko literą prawa można dojść do przekonania, że wszystkie zdjęcia ukazujące się w prasie lub przekazane do publikacji $\mathrm{w}$ prasie należą do gatunku fotografii prasowej. Trudno się zgodzić z takim twierdzeniem. Za fotografię prasową można uznać tylko takie zdjęcie, które zostało wykonane z zamiarem opublikowania w prasie, niezależnie od podejmowanej tematyki i skutku w postaci publikacji. Cechą wyróżniającą fotografię prasową jest zatem jej intencjonalność, a nie sam fakt zamieszczenia zdjęcia na łamach. Zdarza się przecież wielokrotnie, że fotoreporter wykona zdjęcie, ale z różnych przyczyn nie zostanie ono opublikowane. Nadal pozostaje jednak zdjęciem prasowym. Wiele jest natomiast przypadków, gdzie gazeta zwraca się z prośbą do znanego fotografika o udostępnienie jego zdjęcia na swoich łamach, co wcale nie oznacza, że ów fotografik staje się nagle autorem fotografii prasowej. Nie ma większego znaczenia czy autorem fotografii prasowej jest zawodowy fotoreporter, czy też amator, będący jedynie świadkiem wypadku drogowego. Liczy się w tym wypadku fakt, że świadek dokumentujący dane wydarzenie ma na celu przekazanie swojego zdjęcia do prasy.

Informacja, jaką niesie fotografia prasowa jest jej podstawowym wyróżnikiem spośród innych form fotografii użytkowej. Ona stanowi główną wartość zdjęcia i cała forma powinna być jej podporządkowana. Dlatego w fotografii prasowej nie ma żadnych reguł dotyczących kompozycji, plastyki, organizowania barw na płaszczyźnie czy ,zasady złotego podziału" ". Jedyną regułą w fotografii prasowej, jest prymat treści, czyli informacji, nad forma, czyli kompozycją. Oczywiście to, w jaki sposób zostanie przedstawiona treść zależy tylko i wyłącznie od fotografującego. „Pstrykać” może każdy, także automat. Nie każdy jednak potrafi obserwować. Miarą fotografa prasowego jest, zatem umiejętność obserwacji, która urasta do rangi sztuki. Obserwowanie to elementarny proces tworzenia, a rzeczywistość przemówi dopiero wtedy, kiedy się ją zrozumie ${ }^{7}$.

Do związków pomiędzy fotografem, a otaczająca go rzeczywistością nawiązuje koncepcja fotografii prasowej autorstwa Wiesława Hudona. Fotografią prasową określa on jako specjalnego rodzaju dokumentację, która jest wyborem dedykowanym przez światopogląd, intelekt i wrażli-

6 A. Ligocki, Fotografia i sztuka, Warszawa 1962, s. 99.

7 F. Durrenmatt, Wstęp do albumu fotograficznego Bernarda Wicki Zwei Gramm Licht, Verlag Interpress, Zurich 1960. 
wość fotografa. Jest to szczególnego rodzaju zapis, chwytający „temat” na gorąco, bez reżyserii, bez ingerencji w zdarzenie, które zawsze istnieje poza fotografującym i niezależnie od niego.

Fotografia prasowa może przybierać wiele form. Niestety najczęściej spotykana jest fotografia ilustracyjna, która ma na celu jedynie zobrazowanie za pomocą zdjęcia konkretnego artykułu. Takich zdjęć są w polskiej prasie setki. Przedstawiają one szeroką tematykę: wydarzenia polityczne i kulturalne, sport, ekologię, migawki z miasta: środki lokomocji, nowo oddane do użytku budynki, utrudnienia w ruchu, etc. Zazwyczaj jej podstawowym mankamentem jest nieciekawa tematyka, jednak za to nie sa odpowiedzialni fotoreporterzy, lecz redaktorzy decydujący o doborze tematów. Niemniej zdjęcia ilustracyjne mają najczęściej charakter odtwórczy i ograniczają się do dostarczenia suchej informacji na temat fotografowanego obiektu, zdarzenia.

Znacznie rzadziej można napotkać na stronach zdjęcia reporterskie, czyli w sposób świadomy interpretujące daną rzeczywistość. Układ kilku fotografii reporterskich tworzy fotoreportaż, który jest uważany za najtrudniejszą formę fotografii prasowej.

Niestety, nie ma do tej pory powszechnie przyjętej, ani nawet ustalonej, definicji normatywnej pojęcia ,system prasowy”. Większość autorów publikacji dotyczących mediów stara się tylko na swój użytek sformułować definicję tego pojęcia, jak i określić jego zakres. Trzeba przy tym brać pod uwagę przynajmniej dwa istotne czynniki.

Jednym z nich jest z pewnością specyfika działalności poszczególnych instytucji medialnych, które swoim charakterem i sposobem działania praktycznego (warsztatem dziennikarskim) wyraźnie się od siebie różnią. Innymi cechami charakteryzuje się bowiem radio jako środek przekazu i dziennikarstwo radiowe jako rodzaj profesji dziennikarskiej, innymi telewizja i dziennikarstwo telewizyjne.

Drugi czynnik - to pojawiające się wciąż różnego rodzaju nowinki techniczne, nowe sposoby porozumiewania się, nowe instytucje, co do których nie zawsze wiadomo, czy można je uznać za środki masowego przekazu, a pracę ludzi w nich zatrudnionych - za dziennikarzy. Między innymi z tego powodu system prasowy nie ma do tej pory ustalonego zakresu.

Jeśli przez system rozumiemy zbiór współzależnych elementów tworzących całość, która stanowi jednostkę wykonującą jakąś funkcję ${ }^{8}$, to

${ }^{8}$ M. Golka, Kultura jako system, Poznań 1992, s. 64-65. 
taką definicję systemu można z powodzeniem odnieść do rzeczywistości medialnej. Pod pojęciem „system prasowy” można więc rozumieć zbiór (ogół) instytucji uczestniczących - w różny sposób - w procesie komunikowania prasowego o charakterze periodycznym.

Trzeba jednak pamiętać, że system prasowy jako całość nie jest jedynym sposobem porozumiewania się ludzi między sobą. Być może, nie wszyscy uważają go za najważniejszy czy najbardziej wiarygodny. Ktoś może przecież uznać, że cechy takie posiada jedynie bezpośrednia rozmowa lub list, czy urzędowy dokument.

Na system prasowy składają się w zasadzie dwa rodzaje (typy) instytucji medialnych. Pierwszy z nich tworzą te, z rezultatami pracy których czytelnicy i szerzej - konsumenci treści medialnych mają bezpośredni kontakt na co dzień. Te instytucje to przede wszystkim redakcje i wydawnictwa prasowe oraz nadawcy radiowi i telewizyjni. Rezultaty ich pracy to każdy kolejny numer dziennika czy czasopisma, a także kolejno emitowane programy radiowe czy telewizyjne. Każdy człowiek wedle własnego uznania, zainteresowań, własnej woli i potrzeb - może z nich korzystać, oceniać je, wybierać formę kontaktu z nimi, rezygnować z jednych, wybierając inne itp. Nie jest tu istotne czy chodzi o media publiczne, czy komercyjne, wysokonakładowy dziennik czy pismo sublokalne, drukowane w kilkuset egzemplarzach, nadawcę ogólnokrajowego czy stację o lokalnym zasięgu.

Drugi typ instytucji składowych systemu prasowego stanowią takie, $z$ rezultatami pracy których przeciętny konsument mediów na co dzień nie obcuje. Może zresztą nawet nie wiedzieć - bo i nie musi - że one istnieją. Nie oznacza to jednak, że są to instytucje o drugorzędnym znaczeniu, jeśli wziąć pod uwagę sprawność działania systemu prasowego. Wręcz odwrotnie, trzeba podkreślić, że to właśnie od jakości ich działania zależy w dużej mierze sprawność i skuteczność funkcjonowania systemu medialnego jako całości. Przykładem tego typu instytucji są choćby agencje prasowe, bez istnienia których nie sposób wyobrazić sobie dobrego funkcjonowania ani redakcji dzienników czy czasopism, ani radiofonii czy telewizji.

System prasowy, będąc złożoną, całością, stanowi jednocześnie element większej, wielce złożonej całości, jaką jest państwo; nie działa zatem w próżni ani w izolacji. Na jego kształt, strukturę i sprawność w zakresie zaspokajania potrzeb odbiorców duży wpływ mają czynniki zewnętrzne, w tym zwłaszcza warunki społeczno-ekonomiczne, prawne i ustrojowo-polityczne istniejące $\mathrm{w}$ danym państwie. Wystarczy podać 
przykład naszego kraju i sytuację mediów do roku 1989. Kształt i struktura ówczesnego systemu prasowego oraz ogólne zasady jego funkcjonowania były determinowane sytuacją i warunkami państwa ideologicznego, jakim była PRL.

System prasowy ma też liczne uwarunkowania ekonomiczno-społeczne. Widać je bodaj najlepiej na przykładzie prasy drukowanej. Chodzi o to, że w ramach koniecznych oszczędności coraz więcej ludzi przestaje ją regularnie kupować i czytywać, zwłaszcza dzienniki. Potwierdzają to wszystkie badania empiryczne prowadzone w latach dziewięćdziesiątych $^{9}$.

Powyższa próba zdefiniowania pojęcia „system prasowy” jest w części zgodna ze stanowiskiem, jakie reprezentuje J. Sobczak ${ }^{10}$, podkreślając iż systemy prasowe należy analizować z punktu widzenia wolności prasy i ich ograniczeń, badając kolejno ograniczenia w zakresie powstawania $\mathrm{i}$ istnienia prasy (systemu przywileju, koncesyjny, kaucyjny, zgłoszeniowy), treści publikacji (cenzura prewencyjna, represyjna) oraz w zakresie kolportażu (problem debiutu) oraz w zakresie finansowym (stawki i taryfy).

Całkowicie odmienne podejście do systemu prasowego „obowiązywało" przed 1989 rokiem. W modelu autorstwa W. I. Lenina odróżniano trzy warstwy: pierwsza odnosiła się do funkcji prasy, druga do zasad, jakimi kierować się mieli dziennikarze w swej pracy zawodowej, trzecia dotyczyła spraw redakcyjnych, propozycji tematycznych, stylu redagowania, języka, poziomu, sposobu pozyskiwania współpracowników.

Niniejszy artykuł nie stanowi całościowej charakterystyki polskiego systemu prasowego, a jedynie jego pobieżny przegląd. System prasowy w Polsce zmienia się nieustannie, zarówno w sensie jakościowym, jak i ilościowym, a jego pełen opis wykracza poza temat tej pracy. Zawarty tutaj przekrój prasy drukowanej ma na celu zorientowanie, jak duży jest rynek odbiorców fotografii prasowej i dlatego pomijam cały sektor mediów elektronicznych, które stanowią przecież nieodłączny element systemu prasowego.

Transformacja społeczno-polityczna w Polsce, zapoczątkowana w 1989 roku, dotknęła także środki masowego przekazu. To właśnie media z dużym udziałem prasy stały się swego rodzaju papierkiem lakmusowym owych przemian. Znowelizowane prawo prasowe oraz zlikwidowanie na

9 W. Sonczyk, Media w Polsce, Warszawa 1999, s. 12-16.

10 J. Sobczak, Ustawa Prawo prasowe. Komentarz, Warszawa 1999. 
mocy ustawy działającego przez lata monopolistycznego koncernu RSW „Prasa-Książka-Ruch” umożliwiło burzliwy rozwój wszystkich bez wyjątku. Jednym z nich była prywatyzacja i rynkowy „wysyp” tytułów oraz nadawców prywatnych.

Prywatyzacji polskiej prasy towarzyszył również proces przejmowania wielu tytułów przez spółki z udziałem kapitału zagranicznego bądź bezpośrednio przez znane zachodnie koncerny. $\mathrm{Z}$ wyliczeń podanych przez Zbigniewa Bajkę wynika, że kapitał zagraniczny, na początku 1994 roku, posiadał udziały w 56\% gazet ogólnopolskich i 50\% tytułów regionalnych"11. Skalę tego zjawiska jeszcze lepiej obrazują liczby dotyczące wielkości nakładów gazet wydawanych przez zachodnie koncerny. W przypadku gazet ogólnokrajowych udział tytułów wydawanych przez obcy kapitał w ogólnym jednorazowym nakładzie osiagnął poziom 70\% (w odniesieniu do dzienników lokalnych wyniósł on $65 \%)^{12}$. Podobną w rozmiarach ekspansję można było zauważyć na rynku czasopism kolorowych. Na 50 milionów egzemplarzy wydawanych miesięcznie blisko 20 milionów przypadało na wydawców zagranicznych, głównie niemieckich ${ }^{13}$.

Wchodzenie kapitału zagranicznego na polski rynek prasowy wielokrotnie owiane było nimbem tajemnicy i niedomówień. Był to jeden z powodów, które sprawiały trudności w szacowaniu rzeczywistych wpływów zachodnich koncernów w rodzimych mediach. Często również w przejętych przez spółdzielnie dziennikarzy tytułach odsprzedawano kapitały zagranicznym firmom, przy czym nie nadawano tym wydarzeniom należytego rozgłosu. Zmiany właścicieli nie były też na bieżąco rejestrowane. Sytuacja taka doprowadziła w efekcie do powstania ,szumu informacyjnego" związanego z procesem usamodzielnienia się wielu redakcji wspieranych przez obcy kapitał, co dodatkowo pogorszyło atmosferę wokół zjawiska prywatyzacji prasy. W przypadku niektórych gazet, jak choćby „Życia Warszawy” czy „Rzeczpospolitej”, mówiono wręcz o naciskach wywieranych przez konkretne ugrupowania polityczne.

Jednym ze zjawisk towarzyszących ilościowemu rozwojowi prasy na początku lat 90 . był równoczesny upadek wielu pism. W kolejnych latach (od 1991 do 1994 roku) ich liczba wynosiła 97, 358 i 315 tytułów $^{14}$. Nie

11 Z. Bajka, Kapitał zagraniczny w polskich mediach, „Zeszyty Prasoznawcze” 1994, nr 1-2, s. 65.

12 Ibidem.

13 T. Kuczyńska, Gazety z innego świata, ,Tygodnik Solidarność” z 13 maja 1994.

14 W. Sonczyk, op. cit., s. 91-99. 
wytrzymały konkurencji takie pisma, jak „Obserwator”, „Nowy Świat” czy „Spotkania”. Bardzo krótko funkcjonowało również wiele mniejszych tytułów lokalnych. Na podstawie Katalogu mediów polskich za rok 1997 można podać wiele przykładów czasopism instruktażowo-szkoleniowych, które z powodu trudności finansowych i/lub organizacyjno-technicznych zostały zawieszone lub zlikwidowane (w sumie odnotowano około 400 tytułów).

Ważnym elementem polskiego systemu prasowego, biorąc pod uwagę temat niniejszej pracy, jest rynek agencji fotograficznych. Zaczęły one licznie powstawać po 1990 roku, wraz z rozwojem rynku prasowego. Oprócz następczyni CAF - „Agencji Fotograficznej PAP” reprezentującą w Polsce również „AP” i „EPA”, działają również: „Delta Press”; „Agencja Filmowa Axis \& Plot” reprezentująca londyńską „People in Pictures”; „Agencja Flash Press Media” reprezentująca „Getty Images”, „Tony Stone Images”, „Hulton Getty”, „Allsport”, „Minden Pictures”, „Voler Ernst”, „Retna”, „Picture Finders” i wiele innych; „Agencja Piękna” reprezentująca „The Stock Market” z USA, „Yisages” z USA, „Option Pro”, „Jerrican”, „Petit Format”, „SODEFI” z Francji; „Agencja Prasowa i Fotograficzna Europa Press" reprezentująca „TPH”, „HBL”, „Apollo”, „Turkon”, „Omega”, „Illust Tank”, oraz 23 inne agencje zagraniczne; „Bulls Press Poland” reprezentująca „Camera Press”, „Alpha”, „Shooting Star”, „Photonica”, „Fotex”, „Colorffic”, „Kipa”, „Online”, „Elisabeth Whiting”; „Image ML-H” reprezentująca „Focus Photo und Presse Agentur”, „Woodfin Camp \& Associates”; „Polska Agencja Fotograficzna Studio 69"; „Polska Agencja Fotografów Forum” reprezentująca „Reutera”; „Prasowa Agencja Telewizyjna”; „ProPress Pfotography” reprezentująca „Aurora \& Quanta Productions”, ,The Brodgeman Art Library”, ,jump!”, „Picture Perfect”, „Popperfoto”, „Reporters”; „ThETA” reprezentująca „Digital Vision Ltd.”; „Agencja Fotograficzna Gazeta” złożona z fotoreporterów „Gazety Wyborczej”; „Agencja Fotograficzna Super Express” o podobnym profilu oraz jedyna agencja spoza Warszawy - poznański „Tam-Tam"

Pojawienie się fotografii było wynikiem zbiorowego wysiłku wielu pokoleń „reprezentujących różne dziedziny wiedzy, a także sumą doświadczeń wnoszonych przez rozwój chemii, optyki i mechaniki precy-

15 M. Polewska, Źródta newsów - przegląd agencji informacyjnych $w$ Polsce, „Press” 1999, nr 5, s. 62-66. 
zyjnej. Ostatecznie określenie, które to nowe odkrycie miało ująć wspólnym mianem - fotografii, pojawiło się w XIX w. Słowa tego użył po raz pierwszy w 1839 roku John Frederick William Herschel - jeden z tych, którego badania weszły do skarbnicy fotochemii. Był on odkrywcą utrwalających właściwości tiosiarczanu sodu, wchodzącego do dziś w skład utrwalacza. Nazwa „fotografia” nie przyjęła się jednak od razu.

Wertując czasopisma pochodzące z pierwszych lat 40-tych XIX w. widzimy, że dopiero wtedy dagerotypiści wyszli ze swoimi ciężkimi kamerami na ulice, aby fotografować codzienność. Dopiero wówczas ilustracja na dobre weszła na łamy pism. Ilustrowane czasopiśmiennictwo zrodziło się pod wpływem fotografii, która wydobyła głęboko utajony wówczas głód ilustracji ${ }^{16}$.

Rozkwit prasy, jaki nastąpił w połowie dziewiętnastego wieku był $\mathrm{z}$ jednej strony następstwem rosnącego zapotrzebowania społecznego na stałą informację o aktualnych wydarzeniach politycznych, kulturalnych, artystycznych, towarzyskich, handlowych i przemysłowych, z drugiej zaś wiązało się to z rozwojem komunikacji kolejowej oraz łączności telegraficznej; świat począł się wyraźnie kurczyć. Kolej i telegraf przyczyniły się do znacznego przyspieszenia obiegu informacji, budząc dla niej coraz żywsze zainteresowanie warstw społecznych, głównie mieszczaństwa. Już wówczas powstawały pierwsze agencje prasowe: Havasa w 1835 roku, Wolfa w 1849 i Reutera działającej w Stanach Zjednoczonych od 1848 roku, a w Europie od 1851.

Właściwie już wiele spośród pierwszych pism zawierało elementy ilustracyjne, chociażby w postaci winiet tytułowych. Pierwsze ilustracje prasowe to drzeworyty, miedzioryty i staloryty. Do znacznego postępu w dziedzinie ilustracji prasowej przyczyniła się litografia, wynaleziona w 1798 roku przez Alojzego Senefeldera; była to pierwsza forma druku płaskiego. W przeciwieństwie do druku wypukłego (typografii) nadawała się ona doskonale do odbijania ilustracji półtonowych o innych przejściach walorowych, rysowanych tłustą, kreską na kamieniach litograficznych. Znane redakcje korzystały więc $\mathrm{z}$ usług biegłych w tej sztuce rysowników-litografów, którzy przenosili na kamień nie tylko wizerunki ważnych osobistości, widoki miast czy krajobrazów, lecz coraz częściej sceny przedstawiające aktualne wydarzenia. Rysunki takie były opatrzone odpowiednimi adnotacjami, jednak ich zgodność z prawdą była więc różna.

16 L. Płażewski, Fotografia i jej rola społeczna, „Fotografia” 1953, nr 1, s. 2. 
W powszechnym odczuciu szerzyło się przekonanie, że jedynie fotografia może przedstawić obiektywnie i z pełnym autentyzmem świat, ludzi i przejawy wszelkiej ludzkiej działalności. Ale nie znano jeszcze sposobu bezpośredniego przeniesienia obrazu na formę drukującą. Zastosowano wybieg jedyny z możliwych w owych czasach. Uciekano się do współpracy fotografów, jako swoistych pośredników pomiędzy wydarzeniem a rysunkiem litografa na łamach czasopism. Wysyłano więc fotografów, gdy tylko było to możliwe wszędzie tam, gdzie spodziewano się rzeczy istotnych, wielkich lub takich, które zgodnie ze znajomością oczekiwań opinii publicznej czy społecznych gustów i zainteresowań mogły się spotkać $\mathrm{z}$ aprobatą i uznaniem czytelników. Tak więc fotograf dostarczał litografowi zdjęć, ten zaś przenosił mniej lub bardziej wiernie obraz fotograficzny na kamień litograficzny.

Fotografia w tej spółce z drzeworytem i litografią, odgrywała służebną rolę. Zyskała jednak dla siebie pewne profity; powielana bowiem w wielonakładowych periodykach wyruszała w światową wędrówkę w tysięcznych odbitkach, zyskując dzięki temu na znaczeniu. Prasa nie tylko przyczyniła się do upowszechnienia fotografii. W wielu przypadkach zachowała je dla potomności; ileż bowiem dagerotypów i dawnych zdjęć fotograficznych zaginęło lub zostało bezpowrotnie zniszczonych, a jedynym świadkiem ich istnienia pozostały odbitki drukarskie w starych tygodnikach i albumach, jak również jako wolne, oddzielne druki.

Korzystna dla obu stron współpraca rytowników i litografów z fotografami trwała niemal do końca dziewiętnastego wieku. Przełomem okazał się rok 1881. Wtedy to Georg Meisenbach wpadł na pomysł, jak proces fotochemiczny znany w fotografii wprzęgnać do przygotowywania formy drukującej. Sposób nazwano autotypią. Polegał on, na rozbiciu półtonowego, wielowalorowego oryginału na mnóstwo drobnych, wypukłych punkcików. Dzięki temu uzyskuje się w kamerze fotograficznej reprodukującej oryginał przez punktowy raster rysujący obraz za pomocą punktów. Ten rastrowy (zwany też siatkowym) obraz przenosi się na cynkową płytę metodą fotochemiczna, by w końcowej fazie, po wytrawieniu płytki w kwasie azotowym, otrzymać nową, metalową formę drukującą ${ }^{17}$. Ta nowa metoda, wykorzystywana jest po dziś dzień - oczywiście po wielu ulepszeniach i modyfikacjach. Dzięki niej fotografia na stałe zagościła

17 H. Latoś, Z historii..., s. 22-24. 
w czasopismach, i w ten sposób upowszechnił się jej nowy nurt: fotografia prasowa.

Gdy rodziła się fotografia, jeszcze przez następnych osiemdziesiąt lat Polski nie było na mapie Europy. Gdy fotograf polski posyłał swe prace na wystawy międzynarodowe, eksponowano je w pawilonach: rosyjskim, austriackim czy niemieckim, w zależności od zaboru, z którego pochodził. Również jego osiagnięcia, dorobek i nagrody zapisywano nie na polskie konto, lecz zaborcy. Z tego powodu wielu wybitnych fotografów, którzy istotnie mieli co światu pokazać nie brało udziału w międzynarodowych wystawach. Karol Bayer, ojciec fotografii polskiej, albo Walery Rzewuski z Krakowa, nawet w reklamowych ogłoszeniach zaznaczali: „W wystawach udziału nie biorę".

Warto też dodać, że w pierwszych latach istnienia prasy ilustrowanej pochodzenie ilustracji fotograficznej było raczej anonimowe. Rysunki Kossaka, Kostrzewskiego, Matejki, Pillatiego czy innych twórców oczywiście opatrywano nazwiskiem autora, ponieważ malarze wymagali tego od redakcji, a poza tym ich nazwiska podnosiły rangę czasopisma. Z autorami fotografii wówczas się nie liczono: raz zapłacona odbitka stawała się własnością nabywcy. Prawo autorskie jeszcze nie dotyczyło wówczas fotografii, Włodzimierz Spasowicz (1829-1906), prawnik był innego zdania. W 1864 roku, w opublikowanym liście do redaktora rosyjskiego czasopisma „Fotograf” uzasadniał prawo autorskie fotografów do swych zdjęć. Dopiero Marcin Olszyński wprowadził te informacje na łamy „Kłosów”. W ślad za nim poszedł „Tygodnik Ilustrowany”. W obu tych pismach zaczynają się pojawiać nazwiska najpierw fotografów warszawskich, a potem także Rzewuskiego i Szuberta z Krakowa oraz Szajnoka, Edera czy Trzemeskiego ze Lwowa. Tylko fotografowie z zaboru pruskiego nie byli obecni na tych lamach $^{18}$.

Powstanie nowych materiałów zdjęciowych, nowych technologii, doskonalszych aparatów fotograficznych pchnęło na nowe tory rozwój fotografii prasowej. Fotograf wyruszający w plener dostawał najpierw do ręki klisze szklane o suchej bromożelatynowej emulsji, potem - w latach dziewięćdziesiątych ubiegłego wieku - zwojową błonę graficzną, podobną do tej, której używamy dziś.

18 I. Płażewski, Spojrzenie w przeszłość polskiej fotografii, Warszawa 1982, s. $72-80$. 
W okresie dwudziestolecia międzywojennego fotografia prasowa przeżywała burzliwy rozwój. Pojawiały się nowe nazwiska fotoreporterów, powstawały kolejne agencje fotograficzne, jednocześnie coraz częściej publikowane były tematyczne cykle zdjęć. Na czele polskiego czasopiśmiennictwa pod kątem edytorskim, treściowym i artystycznym stał nadal tygodnik „Świat”, którego poziom dorównywał poziomowi publikacji w Stanach Zjednoczonych i Europie Zachodniej (magazynom „Life”, i „Look”, które stanowiły wówczas wyznacznik pism ilustrowanych) ${ }^{19}$. Niestety rok 1939 zatrzymał ten rozwój, a jedynym tematem fotografii prasowej stała się II wojna światowa.

Podejmując wysiłek zilustrowania wydarzeń wojny obronnej 1939 roku, autorzy zmuszeni byli do korzystania $\mathrm{z}$ tego, co ocalało. $\mathrm{W}$ takich zestawach ilustracyjnych funkcjonują więc obok zdjęć autorów polskich również bardzo liczne zdjęcia niemieckie i znalezione w archiwalnych szafach, a najczęściej reprodukowane z hitlerowskich albumów wojennych, almanachów fotograficznych wychodzących w Niemczech podczas wojny i z późniejszych publikacji historycznych. Sporo ilustracji to fotografie powstałe przez kopiowanie pojedynczych klatek filmowych z zachowanych dokumentalnych taśm kronik wojennych. Korzystając z tego szerokiego wachlarza przeróżnych źródeł, można zgromadzić wystarczającą i w miarę kompletną liczbę fotografii dokumentujących omawiany okres. Ale ile w tym konglomeracie jest zdjęć prawdziwie polskich, wykonanych z polskiego punktu widzenia, trudno ocenić.

Wojna i okupacja zniszczyła prawie całkowicie dorobek polskiej fotografii (nie tylko prasowej). Drukarnie legły w gruzach, jak większość naszego przemysłu. Odradzająca się po wojnie prasa polska wydawana była często w warunkach chałupniczych. Pisma drukowane były zazwyczaj na byle jakim, nawet pakowym papierze kiepską, rozpływającą się farbą, nieczynne były działy chemigrafii, brakowało materiałów i urządzeń. W pierwszym okresie po wyzwoleniu prasa polska była więc pozbawiona możliwości publikowania fotografii, a pojawiające się sporadycznie pojedyncze zdjęcia odznaczały się bardzo niskim poziomem technicznym. Na większości z nich nie można było rozpoznać ani osób, ani obiektów.

Fotoreporterzy Wojskowej Agencji Fotograficznej utrwalali każdą chwilę z życia, kształtującej swoje nowe oblicze Polski. Starali się dotrzeć ze swoimi kamerami do najbardziej odległych zakątków kraju, fotogra-

19 M. Fuks, Zaranie fotografii dziennikarskiej w Polsce, Warszawa 1925. 
fując nie tylko wydarzenia wielkiej wagi, ale również codzienną troskę i trud człowieka. Powoli z fotoreporterów stawali się wiernymi kronikarzami pierwszych, niespokojnych lat PRL.

W początkowym okresie działalności agencję cechowała niesłychana żywotność. Tempo, w jakim dostarczała aktualnych materiałów zdjęciowych o tematyce wojskowej i ogólnokrajowej, zaskakuje jeszcze dziś, tym bardziej że ani pośpiech, ani prymitywny sprzęt nie obniżały ich poziomu artystycznego. Nic dziwnego, że wkrótce stała się czołową komórką obsługi prasowej w kraju. Ogromne zapotrzebowanie na dostarczane przez nią zdjęcia może być miarąjej ówczesnych sukcesów, bo przecież, o czym nie należy zapominać, w tym samym czasie działało na terenie kraju kilka innych agencji fotograficznych (Agencja Fotograficzna „Film Polski”, API, SAP, AR).

Regres fotografii prasowej w Polsce powojennej nie polegał na braku umiejętności polskich fotoreporterów, lecz na tym że fotografowali oni taką rzeczywistość, jaką chcieli widzieć redaktorzy odpowiedzialni za publikowany materiał. W ten sposób fotografia reportażowa była zubożona pod kątem tematycznym - Konkurs Fotografii Prasowej był zdominowany przez tematykę wojskową $\mathrm{i}$ „,socrealistyczną”. Fotografia prasowa stała się narzędziem propagandy, co nie pozwalało fotoreporterom na autorskie spojrzenie, a tym samym kreatywność w fotografowaniu zachodzących zjawisk. Prace samodzielne zalegały w prywatnych archiwach, a kiedy ujrzały światło dzienne to były zastrzeżone przez cenzurę.

Bodźcem do zmian stał się przełom polityczny, jaki dokonał się w 1989 roku. Zmieniły się warunki funkcjonowania prasy w Polsce, co znalazło to swoje odbicie także w fotografii prasowej. Rozwiązano Wojskową Agencję Fotograficzną, natomiast CAF rozpoczął okres transformacji, który został uwieńczony w 1991 przyłączeniem do Polskiej Agencji Prasowej, jako Agencja Fotograficzna PAP. Prywatyzacja RSW „Prasa” spowodowała, że większość tytułów zarówno lokalnych, jak i ogólnopolskich znikła z rynku lub znalazła nowego właściciela ${ }^{20}$.

Większość fotoreporterów nie umiała odnaleźć się w nowej rzeczywistości. Zazwyczaj odchodzili oni do branży reklamowej, bądź zakładali własne firmy związane z fotografią. Ich miejsce zajęli ludzie, którzy nie musieli liczyć się już z cenzurą i w fotografowaniu mogli całkowicie zdać się na własny, autorski sposób postrzegania rzeczywistości. Często nie

20 Historia CAF, zasoby internetowe, http://www.pap.com.pl. 
byli oni przygotowani do pracy w redakcji i musieli się wszystkiego uczyć od podstaw. Ci, którzy wytrwali stanowią obecnie czołówkę polskiego dziennikarstwa fotograficznego. Są wśród nich: Krzysztof Miller, Sławomir Kamiński, Adam Golec, Robert Kowalewski, Jerzy Gumowski, Maciej Skawiński, Piotr Grzybowski, Mariusz Forecki. Nie sposób zauważyć, że zdecydowana większość z nich pracuje lub pracowała dla „Gazety Wyborczej”, która jako pierwszy dziennik w Polsce zrozumiała wagę fotografii. W jej ślady poszła „Rzeczpospolita”, która wkrótce stała się najlepiej ilustrowanym dziennikiem w kraju. Oba tytuły („Gazeta Wyborcza” od 1991, a „Rzeczpospolita” od 1999 r.) wydają wielkoformatowe magazyny, które prezentują najwyższy poziom edytorski i przedstawiają najlepsze prace polskich i zagranicznych fotoreporterów.

Zapotrzebowanie na fotografię prasową stale rośnie, co jest wynikiem rozwoju rynku prasy ilustrowanej. Nadal jednak utrzymuje się ogromny dystans pomiędzy Warszawą, a „prowincją”. Pomimo rozwoju nowych środków komunikacji takich jak internet i telefonia komórkowa, fotoreporterowi spoza Warszawy trudno jest sprzedać zdjęcie redakcji mieszczącej się w stolicy.

Niestety, polskiemu ustawodawstwu nie są znane pojęcia ,fotografia prasowa” czy „fotoreporter”. Znaczenie historyczne ma już tylko określenie „reporterskie zdjęcie fotograficzne” wywodzące się z Ustawy z dnia 10 lipca 1952 r. o prawie autorskim.

Obowiązujące prawo prasowe jest kierowane do dziennikarzy zajmujących się różnymi gatunkami swojej profesji, natomiast w bardzo małym stopniu odnosi się ono wprost do dziennikarzy fotografujących.

Ustawa z dnia 26 stycznia 1984 r. Prawo prasowe w art. 7 ust. 2 pkt 4 kwalifikuje m.in. fotografię jako „materiał prasowy”. Z zapisu tejże ustawy wynika, że każda fotografia, niezależnie czy będzie to ilustracja, zdjęcie reporterskie, fotoreportaż, zdjęcie promocyjne czy reklamowe jest materiałem prasowym. Ustawodawca zastrzegł jednak warunek, jaki musi spełnić materiał prasowy. Jest to wymóg publikacji lub przekazania do publikacji w prasie. Kwestia zakwalifikowania zdjęcia do druku nie ma tutaj znaczenia. Nie ma także na to wpływu, czy zdjęcie wykonał zawodowy fotograf, dziennikarz piszący, czy amator, który wysłał je do redakcji.

W doktrynie i ustawodawstwie uznanie dzieła fotograficznego za przedmiot prawa autorskiego następowało nie bez oporów i zastrzeżeń. Przyczyną tego był fakt, że w początkowym okresie rozwoju sztuki fotograficznej dominowały zdjęcia nie wykazujące wkładu twórczego wymaganego do uznania dzieła za przedmiot prawa autorskiego, takie jak 
fotografie do dowodów osobistych, legitymacji, zdjęcia utrwalające zdarzenia z życia rodzinnego lub zawodowego itp. Z czasem zaczął jednak zwyciężać pogląd, że fotografia, tak jak inne dzieła, powinna podlegać ochronie prawnej.

Wydanie każdej gazety i czasopisma powstaje na kolegiach redakcyjnych. Tam najczęściej zapadają decyzje dotyczące tego co ma być fotografowane. Dziennikarze zamawiając zdjęcia, nie biorą pod uwagę tego, czy dany temat będzie wystarczająco plastyczny, a więc jak będzie wyglądał on na fotografii. Zazwyczaj, szczególnie w prasie regionalnej i lokalnej, zamawia się też zdjęcia wydarzeń mało znaczących.

Fotoreporter potrafi dziś sam być scenarzystą, reżyserem i realizatorem, nie może jednak pracować wyłącznie na własną rękę. Ryzykuje pracą „do szuflady”, na co nie pozwala mu chociażby konieczność (i słuszna) rozliczenia się z materiałów fotograficznych, jest rzeczą powszechnie wiadomą, że fotoreporter dla pełnego opracowania tematu musi wykonać znacznie większą ilość zdjęć, niż wymaga tego ostateczna jego forma.

Kończą się czasy, gdy można było bezkarnie wycinać lub kopiować zdjęcia z innych gazet. Zastosowanie w ostatnim dziesięcioleciu w polskiej prasie obróbki komputerowej może jednak zrobić z fotografa kreatora nowej rzeczywistości. W ten sposób również w Polsce zaczynamy mieć takie same problemy z fotografią, z jakimi boryka się prasa zachodnia.

Fotografia jest relacją z rzeczywistości. Nie wolno w niej kłamać ani nadużywać jej. Również czytelnicy są inteligentni, rozpoznają oszustwo, jak stało się w przypadku magazynu „National Geographic”. Zdaniem dyrektora działu fotografii w „National Geographic” - Kenta Kobersteena kwestie etyczne dotyczące tekstu mają zastosowanie także w fotografii. Niestety, wciąż obowiązują dwa standardy: dla tekstu i fotografii. A przecież dziennikarstwo to fakty - niezależnie od formy.

Zdaniem znanego fotografa Leszka Fidusiewicza, żeby zostać fotoreporterem, trzeba posiadać wrodzoną umiejętność patrzenia obrazem. Jeśli ktoś ma „drewniane” oko - nie grozi mu, że nim będzie. To jest podstawa. Najważniejszą cechą według Fidusiewicza jest mieć coś do powiedzenia. Fotoreporter musi mieć wiedzę. Nie będzie dobrym fotodziennikarzem ten, który przeczyta wszystkie najmądrzejsze książki świata, ale jednocześnie nie będzie nim także ten, który wyłącznie fotografuje, a nie rozwija się intelektualnie. A im ma więcej doświadczeń, tym łatwiej i pełniej się wypowiada. Co zaś dotyczy umiejętności, to po pierwsze musi umieć posługiwać się aparatem fotograficznym do tego stopnia, żeby podczas fotografowania nie czuł go, żeby mu on nie przeszkadzał, nie odciagał 
jego uwagi od obserwowania tego, co fotografuje. A po drugie musi być elastyczny w pracy kiedy idzie na temat z określoną koncepcją, z narzuconymi sobie ramami, ale okazuje się, że przebieg wypadków jest inny, to musi się potrafić przestawić na inne tory.

Często ludzie odrzucają prawdę o świecie, wolą wyreżyserowane zdjęcia gwiazd zamiast prawdziwego życia, grę pozorów zamiast prawdy. Obiektyw jest granica, która musi dzielić fotografującego od otaczającego go świata. Tuż po wypadku Diany szczególnie napastliwie atakowano fotografów za to, że nie pomagali w akcji ratunkowej, a fotografowali. Fotoreporter nie może być outsiderem, fotografować „na zimno”, a zarazem włączać się do akcji, na przykład pomagając w ratowaniu ofiar.

W Polsce, jak dotychczas, nie wykształciło się lobby fotografów prasowych, brak jest samorządu zawodowego, a istniejące zrzeszenia dziennikarzy nie mają w swoich strukturach sekcji fotograficznych. Taki stan rzeczy sprzyja deprecjonowaniu roli fotografów w środowisku dziennikarskim, co znajduje swoje odbicie wśród naukowców zajmujących się tematyką prasoznawczą.

Niestety, nic nie wskazuje na to, aby opisany stan rzeczy zmienił się na lepsze w najbliższej rzeczywistości. Tylko niewielka część fotoreporterów jest zainteresowana przerwaniem obecnej stagnacji w tym względzie, ponieważ wiedza większości z nich na temat wykonywanego zawodu jest niewielka. Istniejące obecnie na rynku czasopisma fotograficzne kierowane są głównie do amatorów, a większość artykułów poświęcona jest nowinkom technicznym i testom oraz rankingom sprzętu. Nieliczne artykuły, dotyczące fotografii prasowej koncentrują się wokół wyników kolejnych edycji Konkursu Polskiej Fotografii Prasowej i na wywiadach z jego laureatami. Brakuje na rynku pisma, które jednoznacznie położyłoby nacisk na publikację dobrej fotografii autorstwa rodzimych fotoreporterów. Także przyszłe normy prawne powinny sprecyzować niektóre pojęcia, takie jak „osoba publiczna” czy „dobra osobiste”, a także odnieść się do problemów fotografii cyfrowej, która jest w znacznie większym stopniu podatna na manipulację niż jej konwencjonalna poprzedniczka. W rezultacie, może ktoś dokona też analizy i opisu relacji pomiędzy fotografią prasową a innymi gatunkami dziennikarstwa. 


\section{Summary}

Press photography is not a frequent subject of press specialists' considerations although it is an inseparable component of contemporary newspapers and magazines. The great part photography plays in the contemporary world in conveying information, spreading knowledge, shaping opinions and social, political and cultural attitudes is frequently forgotten. It should be sought in its universal character on the one hand and in its imminent authenticity and utter believability of its presentations on the other. Together with woodcuts and lithographs it played a supporting part. However, it has won certain privileges. It was copied in high circulation periodicals and wandered the world in thousands of copies thus gaining importance. The press has not only contributed to photography becoming common. In many instances it has preserved photographs for the posterity as an uncountable number of daguerreotypes and old photographs have been lost or destroyed forever and the only evidence of their existence have been their printed versions in old weeklies and albums, as well as separate prints. 